\title{
Early Ethiopian Christianity: Retrospective enquiry from the perspective of Indian Thomine tradition
}

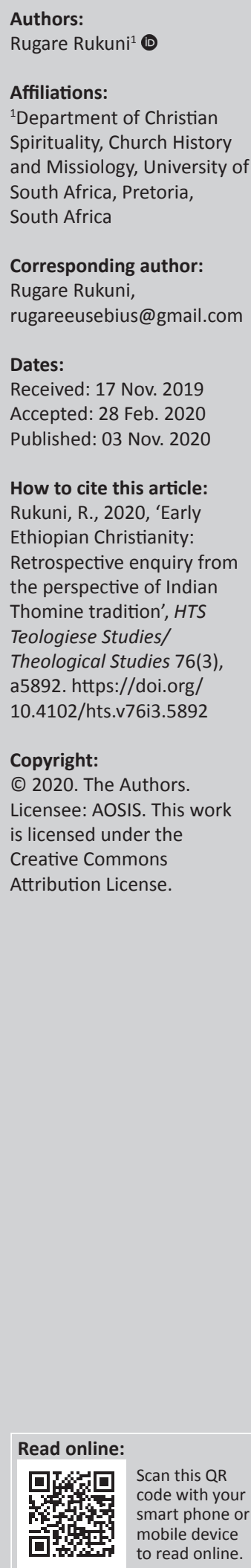

Ethiopian Christianity's narrative is aggregately established with an explicit aversion to the account of the Ethiopian Eunuch in the Lukan Acts (Ac 8). The preceding practise neglects a cardinal record in Christian history, as arguably the Book of Acts is the basicsource for 1st century Christianity. The main arguments for this approach derive from the lack of detailed archaeological data for the existence of Christianity before the Negus Ezana. However, this also evades the reality of the Judaic-Ethiopic connections as a substantial premise for the early interaction of Christianity with Ethiopia. Document analysis complemented by the archaeology of religion and cultural historiography were used in this study. A parallel review of Indian Thomine tradition and integrated maritime connections with Aksum developed a case for the establishment of a 1st century Christian account for Ethiopia. The approach of this study entailed the perception of Ethiopian Christianity in its organic native context and not necessarily as a derivate of Christianised Syria or Egypt.

Contribution: A parallel review of Indian Thomine tradition and integrated maritime connections with Aksum developed a case for the establishment of a 1st century Christian account for Ethiopia.

Keywords: Christian history; Ethiopia; India; Thomas; early Christianity.

\section{Introduction}

While Ethiopian Christianity has been deduced as a 300s CE phenomenon, a late comer in the narrative of Christianity and the one detached from biblical and apostolic tradition, there appears to be ground for alternative theorem. A case for 1st century CE Christianity in Ethiopia is derived from the biblical account of the baptism of a diplomat titled an Ethiopian eunuch in Acts 8:26-38. The reference to Ethiopia, possibly Aksum, a notable empire South of Israel adjacent to the Arabian Peninsula, adds ground for the investigation regarding the possible existence of Christianity before Ezana (cf. Kaplan 1982). This theory would be deriving from the parallel spread of apostolic Christianity in related regions such as India. The royal conversion of Ezana through the Syriac influence of Frumentius is a 4th century CE phenomenon. Although this tallies with the established epigraphic and literary documents pertaining to Ethiopia, this does not corroborate a relatable synthesis with the New Testament Lukan Acts. The visibility of Ethiopia and Southern Arabia in Hebrew heritage, as recorded during the golden age of Solomon, logically implies that in the effort to spread Judaism's protégé Christians inadvertently would assert their position firstly amongst those relatable to Israel and Judaism.

The preceding assertion is logical when the Jewish-Christian schism is determined chronologically as a phenomenon of the 2nd century CE (Boyarin 2010:3, 26-27; Nickelsburg 2003:195-196). Therefore, when cognisant of the nature of Christianity that was not subjected to the Jewish polemic that characterised the 2nd century $\mathrm{CE}$ and the shared practises between Judaism and Christianity in the 1st century CE, there is substantial ground for the possible interaction between apostolic Christianity and the Judaised Ethiopian nation that claimed the title of the new Zion and dually would embrace the new faith that emerged from Judaism. If these claims can be verified using archaeological evidence, this redefines the narrative of early Christianity altogether.

\section{Method}

There was a systematic examination of documents through document analysis (cf. Bowen 2009:27; Ritchie \& Lewis 2003). This document analysis facilitated a literature review, which entailed various aspects and allusion to several methodological approaches. Complementarily there was an emphasis upon cultural context through the use of cultural historiography (Danto 2008:17). Parallel to this, the author implied an adaptation of this method upon the study, which evaluated the narrative from the perspective of enculturation and self-definition as correspondent to the discussion regarding religious-political complex (Rukuni 2018:156). Insights were derived from the archaeology of religion as commensurate with the essential nature of the argument (Insoll 2004:59). 
Dually archaeology evaluated the literary evidence under examination (Insoll 2004:61; Yamauchi 1972:26).

\section{Apostolic Ethiopia as per Acts 8:26-38}

There is a painting by De Pujol (1848) that depicts the baptism of the Ethiopian Eunuch as described in the Book of 8 which is dateable c. 63 CE (Carson et al. 1973-2014). The two historical sources (painting and the New Testament manuscript), although distant in time and setting, incite an enquiry regarding Ethiopian Christianity.

Acts 8:26-38 is a 1st century CE account of the geographical dispersion of a religion conceived within Judea (Eusebius $H E, 3.4$; ed. Schaff 1885b:184), whilst on the other hand the picture is a depiction of this event during a post-enlightenment era and the age of romanticism. Arguably, the artist was far removed from the depicted event and Christianity then prevalent, although apparently his views were shaped by a version of Christianity dominant in his time. The preceding statements form an immediate observation, which does not however deconstruct the provoked enquiry regarding the possibility of an Ethiopian Christianity with apostolic ties.

To begin with the narrative in the translated manuscript of the Lukan Book of Acts is a Christian history narrative aggregately depicting the dispersion of Christianity by apostolic connections (cf. Inowlocki \& Zamagni 2011). The accounts of Lukan Acts are confirmed by an external source from the 2nd century CE Muratorian Canon c. 170 CE (Kirby 2001-2019). From the perspective of the established gap between Ethiopian Christianity c300CE and 1st century CE apostolic Christianity, the preceding sources observed denote an inceptive step into this study. Whilst the narrative of Acts is an arguably illustrated one, a metaphoric euphemism is deductible in harmony with other biblical passages. That is, the very narrative itself can be implied as an iconic reference to the intrinsic Christianisation of Africa as in this case represented by Ethiopia.

Firstly, the assertion that the directive to go meet the Ethiopian Eunuch came at the instruction of an angel resonates with transformative or precedent-like narratives within the epoch of apostolic Christianity as depicted in the Book of Acts (Ac 8:26). A prominent example that comes to mind is the vision and angelic encounters of Peter in Acts 10; these provoked tension as depicted in chapter 11. The ensuing events precipitated by Peter's divine encounter, which had implied an instruction to dynamically make contact with non-Judaic individuals, consummated with the first recorded conciliar assembly and resolution in Acts 15. Hence, perceivably, the angelic encounter in this scenario implies an ensuing event of definitive proportions to the Christian movement.

Secondly, the geographical direction has arguable metaphoric significance; the angel commanded that Philip should go southwards along the road leading from Jerusalem to Gaza. Notably, the mention of the South resonates with several Old Testament citations regarding Ethiopia, Psalms 68:31; Zephaniah 3:10, a case used by Donatist to build up their Africanism cause (Augustine Letter 93.8.24; Wilhite 2017:221). In spite of the later adaptation of these texts by African Christians, the direct allusion to the relevance of Africa in the Divine cause that commissioned the apostolic church is arguably evident. In addition, another intrinsic biblical argument is Jesus' positive reference to the visit made by the Queen of the South (Queen Makeda) to Solomon (1 Ki 10:129; Mt 12:41; Dashu 2012:1-7; Kebra Naghast 25-32, Budge 2000:21-33).

Alternatively, Queen Makeda's visit is to be understood as a heathen or polytheistic nation's response to the concept of Israel as the loci of Hebraic monotheism (Dt 28:10, 1 Ki 4:34; $8: 60)$. With respect also to this research, the mention of the road leading to Gaza raises the subject of the Arabian Peninsula, a locale that prior to Islam saw a convolution of religions consequent of multiple external influences. Notably, Aksum or Ethiopia also had a client Christianity thriving there in certain regions (ed. Dewing 2017:1:32-33; RIE I-III et al. 1991-2000; Procopius, Wars 1.20.3).

Finally, the narrative established the persona of the Ethiopian Eunuch and conjointly his mission to Jerusalem.

That he was a diplomat has led to conclusions by archaeologists and historians that somewhat detach religious significance from his visit (cf. Phillipson 2012:195). This is premised on ancient silk, spice trade routes that hint that there were significant geopolitical ties between Aksum or Ethiopia and regions such as Israel (Cerulli 1959:5-28; Periplus of the Erythrean Sea, ed. Schoff 1912:23). Corresponding to this line of thinking, the Book of Isaiah in the hands of the diplomat becomes a goodwill gesture or some purchased antique and not essentially a document of convictional intent. This defies the claim by an authenticated source, the Book of Acts, that he

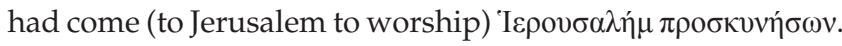
He was likely a proselyte Jew, that is, one by circumcision (Josephus Wars 5.3.1; O’Bannon 2016:1408; Mt 23:15). Having established that he was a significant dignitary of the Aksumite kingdom, one bound to demanding claims of loyalty to the Ethiopian monarch consequent of his description as a eunuch, the record that he was here mentioned as explicitly practising a foreign religion has deductive implications.

The religious-political matrix of Ethiopia at this stage in the 1st century CE was arguably symbiotic as the rest of the antique world (Rodinson 1964a:184; Ullendorff 1956:219). Logically, it can be argued with allusion and inference on other geopolitical powers within this era, the most prominent being the Roman empire. In spite of being polytheistic, the emperor even had a cult at some point, and implicatively court officials and the senate had to accede or rather face antagonism (Lee 2006:175). This therefore implies that the practise of Judaism was an acceptable norm 
in the Aksumite court in the 1st century CE. This corroborates a composite argument when reviewed from the perspective of the (Kebra Naghast 53-55 Budge 2000:67-71).

Furthermore, in an anachronistic application of the principle, Cuius regio, eius religio (Latin), meaning, 'he who rules, his religion', certain deductions are consequent (Wilhite 2017:340). It therefore implies that if a part of Ethiopian nobility had contact with apostolic Christianity and returned to court as a conformant, Christianity arguably had a place in 1st century CE Ethiopia. In the minimum, this entails an enquiry into Ethiopia's position within the corpus of apostolic tradition.

\section{Apostolic tradition and the conversion of natives beyond the influence of Rome}

Tradition as deduced from the apocryphal sources also adds to the narratives of Lukan Acts in an informative manner, thereby filling in certain gaps regarding the expansion of Christianity. A prominent example in this case is the tradition relating to Thomas as depicted in The Acts of Thomas (Thomaskutty 2018:120). Notably, this can be aggregately reconciled with the historical accounts as derivate from classical, traditional-historical and patristic writings.

The relevance of Thomas stems from his association with the propagation of the gospel to India and Persia and with some debate to southwestern India (cf. Brown 1956). Intricately, the latter claim concerning southwestern India was made by a Syrian sect of Christians in a region called Malabar (Davidson 2004:154). The observation regarding the geographical exploits of Thomas revolves significantly around the nativity and the organic nature of the resultant orthodoxies in those regions. The Christian practise in these areas had a significantly non-Roman shade and therefore intrinsically resembled a not-so Hellenised form of Christianity (Davidson 2004:155; Tilley 2006:386-387). The immediate consequence of this notion is the observed fallout with the imperial-clerical symbiote that emerged in the Constantinian era, because of the entrenched enculturation of these divergent Christianities, the emergent orthodoxy in spite of an imperial was not overwhelming enough (cf. Behr 2004:157; Roldanus 2006). Arguably, by extension, the native and divergent form of this Christianity when placed on an index of relativity with Roman Christianity creates a basis for another argument.

Tilley's assertions regarding the affinity of Christianity in Carthage with Jewish elements surrounding the region corroborates the argument (Tilley 2012:386). This is substantiated by the Hebraic nature of the Carthage Christians' Latin Bible and Tertullian's resonance with ideology illustrated in the Talmud and Mishnah.

In addition, Tertullian regarded the historicity and the precedent nature of the Jerusalem assembly's conciliar resolution as reflected in Acts 15:19, in Apol. 9.13. Tertullian refers to the abstinence from blood consumption as standard Christian practise (ed. Schaff 1885a:35). Finally, the reference to Jewish feasts in the 5th century CE Christianity is an indicator (Fourth Council of Carthage, canon 89) (ed. Tanner 1990). These connections to Jewish Christianity and Judaism are a subject of aggregate immensity, which have been treated in other papers by the author; however, they compose the argument of the possibility of Christianity in certain localities being derivated from 1st century CE apostolic Christianity (Alexander \& Smither 2015:171).

This becomes a case in point in particular reference to Ethiopia. The practise and parallelism to Judaism and Jewish Christianity should arguably be considered as evidence in this regard (Rodinson 1964b; Ullendorff 1956, 1960). The perceived gaps as a result of the lack of archaeological data placing this Christianity within the 1st century CE may aggregately be deduced as a matter of subjective perspective. Insoll insists on the expansion of archaeological methodology in religion to include significant attention to ceremony, rituals and diet amongst other things (Insoll 2004:47). From the perspective of a methodology that derives from an interdisciplinary approach between archaeology and anthropology, social and religious culture intrinsically builds a case for archaeological evidence (Binford 1962:218, 219). Deductively, the claim for an apostolic connection within Ethiopian Christianity implies an archaeological case to establish the existence of Christianity during the 1st Century CE.

\section{The archaeological quest for early Ethiopian Christianity}

The attempt to reconcile Ethiopian Christianity to the 1st century CE apostolic Christianity is one that should derive from parallel establishments of African Christianity before the 2nd century CE. In a generic reference of established theorem in the history of Christianity capable of serving as a guide to the archaeological framework, the research rivets to deductions from Harnack.

Adolf von Harnack is credited with the conceptual study of Christian demographics. Based on an analysis of literary data, Harnack made deductions regarding the existence of Christian civilisations (Trombley 2006:302). Derivative from Origen and Tertullian Harnack deduced evidence for Christian civilisations wherever there was either a martyrdom narrative or evidence for a bishopric (Trombley 2006:302).

The historical study of Christianity can consequently base upon inscriptions, papyri and archaeological artefacts. The preceding mentioned group of evidence qualifies for demographic analysis. Notably, Trombley asserts that these (inscriptions, papyri and archaeological artefacts) actualise, 'the localisation of early Christian communities at particular sites and historical moments, as long as dates can be assigned with relative precision' (Trombley 2006:302). 
Harnack's conceptualisation of the geographical spread of Christianity therefore significantly composes framework theorem in the study of Church history. Dually, this theory coupled with Bauer's ideology of heresy and orthodoxy detachably formed modular loci in the deductions regarding the spread of Christianity around the world. The particularisation of Christian geography serves a definitive objective in the study of Church history. Given the focus on Ethiopia in this investigation, it is necessary for a parallel application of the demographic analysis in ascertaining the Ethiopian religious political matrix.

In a deductive conceptualisation, following the conclusions from Harnack, it was deduced that inscriptions, papyri and archaeological artefacts formulate specific territorial Christian narratives. Ethiopian Christianity, famed for the inscriptions of Christian monarchs such as Ezana and Kaleb, illustrated gospel manuscripts and the diverse rock-hewn churches, therefore qualifies for a review and investigation with reference to Harnack (Phillipson 2012), especially in the capacity of these factors to corroborate and substantiate the existence of martyrdom and the existence of an episcopal see. These elements thereby become instrumental in determining the existence of a Christian civilisation and also definitively distinguishing it.

\section{Ethiopian Christianity and Harnack's theorem}

The investigation therefore scans for these elements with regard to Ethiopia with the objective of implying a chronological narrative for Ethiopian Christianity; that is, bridging the discrepancies that make the Ethiopian Christian narrative sketchy. The application of deductions from Harnack also enhances the definitive review of Ethiopian Christianity and its political-religious matrix. The preceding contributes to a holistic Christian narrative, especially when carried out as a parallel review of Constantinian dynamics in Christendom. This serves to establish Ethiopian Christianity as an autonomous significant unit of the Christian narrative with composite importance to a complete Early African Christian narrative.

In compliance with the deductions made as to the theorem for the spread of Christianity, Ethiopian Christianity has to be examined using papyri, inscriptions and archaeological artefacts, to substantiate martyrdom narratives and the existence of episcopal sees. This has been factored by the archaeological and anthropological work on Ethiopia (cf. Bowersock 2013; Finneran 2007; Phillipson 2012; RIE I-III et al. 1991-2000; Ullendorff 1956). The objective of the investigation is rather a corroboration of a narrative parallel and correspondent to the rest of Christendom. The preceding will be facilitated by the evidence.

It is the presumed deduction of the research that in spite of the comprehensiveness of the narrative of Ethiopian Christianity, it has relatively been excluded from the respective contemporary collection of Christian narratives.
Ethiopia arguably has claim to apostolic origins; the biblical narrative regarding the baptism of the Ethiopian Eunuch is a starting point (Ac 8). The deduced silence of Christianity in Ethiopia in the first three centuries of its inception could possibly be a factor of missing or undiscovered data. Irrespective of the preceding factor, Ethiopia by extension was part of the Byzantine Christian matrix through its subservient link to Alexandria (Binns 2017:43; Hendrickx 2017:10).

Given the above-mentioned perspectives, it therefore implies that Ethiopia should be composite to narratives of early Christianity and Byzantine Christendom given its significance. The preceding deduction is composite to a justification for the parallel review of Ethiopian Christianity with the rest of Christendom across eras.

Therefore, this starts with positioning Ethiopian Christianity within reference to other divergent 1st century $\mathrm{CE}$ Christianities, and then within its African regional influence.

\section{A similar scenario: Thomas and Eastern Christianity (India and Parthian-Persia)}

Parallel to Ethiopia's unique tradition and Christianisation narrative is the story of Thomas and his missionary exploits in the eastern regions of the world, resulting in the phenomenon of Eastern Christianity. Notably, sections of Eastern Christianity such as Syrian Edessa were included in the Bauer thesis (Bauer 1971:27, 59, 79). The Christianity of India and Persia, the composite units of Eastern Christianity, relates to Ethiopia in a bi-sectional connection. The first direct sync is derived from the category of Eastern Christianity to which Ethiopia is significantly attached. Consequent to this approach, Ethiopian Christianity when positioned in contrast to Nicene orthodoxy and the Chalcedonian definition usually forms part of an index that places it within views characterised as Eastern (cf. ed. Bausi 2012). The former assertion is usually justified based on Ethiopia's Coptic and Syrian connections (cf. Isaac 2013:109-110, 252-253). The Syriac denotation mutually derives from antique clerical-royal romanticism of Frumentius with Ezana which led to the initialChristianisation (Kaplan 1982:101-109; Munro-Hay 1988:111-127) and the second wave of Syrian ascetics that aggregately shaped medieval Ethiopia (Munro-Hay 2005:137-168). By extension, the connection through the derivation of clerical authority from Alexandria by the Abuna who is the Ethiopian version of the Coptic patriarch entails the denotation Coptic.

Notably, the two renditions of Coptic and Syrian entail an aggregately imported version of religion, that is, Christianity in Ethiopia from this perspective is reflective of mainly exotic composition. By referring to the Judaic past of Ethiopia as a characterising feature of the religious background, the narrative and connotations are redefined. The preceding attempt adds weight to the pursuit of an early Christianity for Ethiopia that was parallel to apostolic tradition. Indirectly, 
the investigation by pursuing an apostolic origin narrative for Ethiopian Christianity observes the prevalent apostolic tradition of Thomas that characterised Eastern Christianity (Pothan 1968). Deductively, the balance between substantiated archaeological-historical evidence and oral tradition is weighed from the perspective of the history of this respective strand of Eastern Christianity.

Therefore, in this respective section, forming a prelude to substantial discussion and partial analysis of this connection is implied. Given the objective of the prelude is a case for the establishment of an Ethiopian apostolic origin narrative, the aspect that relates to the apostolic connection of Eastern Christianity is what is discussed here. The connection that relates to the influence of Syrian Christianity and the positioning of Ethiopian Christianity amidst Nicene and Chalcedonian orthodox-polity dynamics is discussed in designated sections in related papers by the author. Unlike Ethiopia, Thomas and his encounters with Persia and India are recounted from several traditions and patristic works dated to have been within the first 400 years of Christianity.

\section{The geographical detail of Eastern Christianity}

The connection of Eastern Christianity to the apostolic mission of Lukan Acts is definitive in Acts 2:5-11, where there is reference to sections from the Parthian Persian empire, that is, Parthia, Media and Elam (Moffet 1998:4). Notably, a geographical delineation of the world of the apostles had been accomplished by the Pontian Strabo. Strabo positioned Parthian Persia and Assyria in the East with their eastern regions bordering India. Correspondingly, Arabia, Syria and Asia Minor were depicted in the West (Moffet 1998:5).

Strabo however implies less information regarding India proper, the region beyond the Indus river; this is because of the professed ignorance of Arab and Greek-Egyptian mariners who held monopoly in merchant trade (Strabo, Geographica 15.1.37; ed. Jones 1917-1932:63-67; Moffet 1998:5).

A notable connection is the existence of antique relations between India and Israel that date back to the legendary days of King Solomon. Israelite opulence was buffered by exotic goods, some of them from India (Katz 2000:27). In addition, it seems that Buddhist narratives such as the Mahoshadha Jataka derived from Solomon (Philip 1908:24). There is an account that parallels 1 Kings 3:16-28, which replaces the adjudication of Solomon with that of Buddha (Skolnik \& Berenbaum 2007:9:772). Given the preceding observations, it implies that India and Israel were ancient trade partners and dually that the renowned wisdom of Solomon was an emulated notion. Retrospectively, the Kebra Naghast's main account of Queen Makeda that parallels 1 Kings 10 similarly builds on the legendary reign of Solomon (Budge 2000). This creates a chronological nexus regarding contact between India and Ethiopia. In addition to the existence of evidence substantiating the aggregate link from Hoddu (India) to Kush (Ethiopia) during the later reign of Parthian king Ahasuerus (Es 1:1, 8:9; Bhaskaran [2012:40]), it appears that there is a case for contact between Israel and India. The preceding deduction dually implies a corresponding network of influence in which Ethiopia participated.

In a comparative analysis, the historical geographical knowledge of Ethiopia and its surrounding region that dates back to the 1st century CE is also available. Courtesy of Cosmas, the great Christian expeditioner, the significant port of Adulis is brought to view (Christian Topography III 65; Wolska-Conus 1968-1973, 1:502-505). Even for later eras, the diplomatic and economic involvement of Ethiopia implied it was more than a reference on historical maps but a significant locus within its region (Periplus 4; Casson 1989:51, 52).

Deductions can be made regarding reference to the diverse nationalities in the Book of Acts that correspondingly implied the geographical expanse of the apostolic mission. The account of the Ethiopian Eunuch and corresponding reference to directions pointing generically to the southern land of Ethiopia possibly act as an indicator of the composite relevance of Ethiopia to the apostolic mission. Ethiopian Christianity is intrinsically riddled with origin tradition. It therefore would be logical to review the Eastern Christian origin and apostolic traditions as an informative parallel from which to derive the Ethiopian narrative.

\section{The Apostle to Asia}

The Edessan account c200 CE titled Acts of Thomas (ed. James 1924) denotes Thomas as the apostle to India; this apocryphal document is one of several apocryphal Acts dated to the 3rd century CE. The Acts of Thomas distinguishes itself as the most ancient document with respect to Asian Christianity. Thereby, it completes the continuum that is derived from Lukan Acts' reference to the apostolic mission in Asia.

Arguably, the tradition's ancient nature and supporting evidence increase the probability of foundational factuality to this improbable legend (ed. Rapson 1922:579; Smith 1906).

The account of the Acts of Thomas opens as an extension to the Lukan Acts, with suggestions of an apostolic gathering for the purpose of designating geographic mission responsibilities. During this meeting, India was assigned to Thomas. Underneath 1 have reformulated a translation of the opening remarks in the Acts of Thomas (Acts Thom 1:1; ed. James 1924):

During the division of the regions of the world, specifying where each one of us should go, that is to the designated region and respectively the nation to which the Lord appointed him. As per the procedure, accordingly, India fell to Judas Thomas, who also is known as the twin: he attempted to resist, basing his argument on his health as an incapacitation and additionally his Hebraic 
nationality as a caste factor that would inhibit his interaction with the Indians. (p. 1)

From the perspective of the New Testament narratives of the gospel, the apocryphal account thereby derives some credibility by relating to the character of the gospel Thomas. The congruence with his inquisitive and aggregately pessimistic personality (Jn 20:27-29, 14:5), thereby implies some form of continuity between the Acts of Thomas and the canonical texts. In addition, the recount concerning an apostolic meeting could be a reference to Acts 1:13 where the mission of the Christian church commenced, or other correspondent meetings of a similar nature that resulted with the developing mission worldview of the early church (Mitchell 2006:295-301). Mention of the city Adrapolis (Sandaruk, in Syriac) is a possible reference to Nomos Andropolites, which was a provincial capital in-route to India via the Nile. Moffet asserts that the significance of the account lies in its observation regarding the modus operandi of the apostolic mission regarding the gospel to Jews. Notably, the Second Diaspora Jewish communities were foundational to the Asian missionary establishment (Moffet 1998:27). The particular reference to a flute girl one of the initial converts' race as Hebrew affirms this notion Acts Thom 1:5 (ed. James 1924:3). Dually, the manner in which the text plays out as a romance that has derivatives from the gospels and the rest of canonical books is aggregately explicit. This observation has implications upon Ethiopian Christian tradition, which has significant parallels to Eastern Christianity's origin story in this regard. In addition, literary and historical data substantiates the accounts of Acta Thoma by affirming the existence of Christian groups in diverse parts of the Parthian empire within the 1st century CE (Ac 2:9; Gorder 2010:24).

\section{The royal connection}

Thomas' persistent rejection to accept the mission to India even after the epiphanic appearance of his Lord and God Jesus Christ Acts of Thomas 1:1 is broken by the introduction of a narrative divergent from traditional apostolic records (ed. James 1924:1; Jn 20:28). In a narrative that reads out like the record of the Abyssinians by Theodoret and Rufinus, which mentioned a capsized ship, court servants Frumentius and Aedesius and the king Ezana (Amidon 1997:18-20; Theodoret Hist; Eccles 1.22, ed. Schaff 1885c:127; Rufinus, Hist. Eccles. 10.9-10); then the Acts of Thomas alludes to a contractual obligation of Phillip as a carpenter to the Indian king Gundaphar as the source of his missionary work in India. Amusingly, reference to Jesus selling Thomas into servanthood so as to have him engaged with the evangelistic appointment that was his due in India is notable (Acts Thom 1; ed. James 1924:1-2). Therefore, Thomas arrived in India under the guise of a craftsman but with the ultimate intention of preaching Christianity within the region. So successful is his endeavour that Thomas makes an attempt at converting the monarch (Acts Thom 2:22-27; ed. James 1924:9-11).

Another distinctive feature of Thomas's version of Christianity is his spread of the doctrine of chastity, a notable characteristic of certain ascetic sections of Eastern Christianity. Within the legend, this component of his message brings him imminent death at the command of King Misdaeus (Mazdai in Syriac) (Acts Thom 13:167; ed. James 1924:74). In continuity with the Ethiopian tradition of origins and some form of parallelism to Pauline missionary methodology, Thomas appointed a deacon, a certain Xenophon, to remain in charge in the regions of Gundaphar (Acts Thom 7:66; ed. James 1924:77). This resonates with the aura surrounding the emerging episcopal polity in the 2nd century CE within Christendom.

Jha (1998-2010:115) corroborated the Thomine tradition as derived from Acta Thoma and thereby asserted the historicity of Thomine tradition within the 1 st century CE. In conformity with the tradition as derivate from the Acts of Thomas, Jha mentioned Gondopharnes as the Indo-Parthian monarch over northwestern India.

Together with Thapar, Jha argues for the martyrdom of Thomas in Tamil Nadu near Chennai (cf. Thapar 2015). Although aggregately it appears the date that is prevalent in many versions of tradition is $52 \mathrm{CE}$ as the inception of Thomas' mission India (Kalyanaraman 2019:4-6).

\section{The Thomine tradition as a modern discussion}

Since the 1900s, Thomine tradition has remained a relevant discussion in Indian and Indus circles; the historical implications of the authenticity of the Thomas tradition arguably define the religious history of a substantial region of Indus civilisations. The implications of an intrinsic 1st century CE tradition appear to cover the territories of Pakistan, Iran, India and Afghanistan. The tradition however has had a significant share of attention in academic, political and religious circles it would appear. Therefore, the revisionist archaeology is an additional attempt on affirming or deconstructing the tradition. Significantly, archaeology has functioned as a key factor in substantiating both arguments. Examples are the re-examination of the Taxila cross and the current research on the reality of the maritime interconnections in the 1st century silk and spice routes.

Kalyanaraman debuted the Taxila cross as ingenuine and as an unauthentic source to verify the mission of Thomas in India (Kalyanaraman 2019:1). The Taxila cross can be perceivably decoded in stamp seals associated with the decline of the Indus civilisation (Dales 1968). An intrinsic attention to the Indus Script and its composite hieroglyphs proves the + sign when synced with a svastika represented rather a fire-altar and सत्त्व (sattva) in the Sanskrit language, respectively (Kalyanaraman 2019). Whilst the altar represents Hindu worship, the सत्त्व (sattva) is an element of Hinduist philosophy. Kalyanaraman, an Indian native, thereby assigns the find of the Taxila cross and its use as an affirmation of the Thomine tradition to be attempts at endorsing foreign religious concepts into an indigenous history. The Taxila 
cross was found in 1935 by a British-appointed commissioner in the region of Rawalpindi. The ancient site, the city of Sirkap, from which the cross was found was itself datable as 1st century CE (Kalyanaraman 2019:2). Hence, adding to the momentum of 19th and 20th century missionary Christianity, the British commissioner affirmed the established Christian roots of India.

This arguably is a fact that incites Kalyanaraman's affirmative denunciation of not only the Taxila cross artefact but also the legend and tradition associated with it. In other words, the ultimate end of Kalyanaraman's argument is that the Thomine legend is based on little, if any, authentic archaeological and historical evidence (Kalyanaraman 2019:46). Kalyanaraman argues against the continuum of perceived revisionist history that emerged from this deductive find (Taxila cross). Consequent of the impact created by an archaeology of apostolic Christianity in the Indian Christiancultural-religious matrix, there were direct implications for indigenous Indus expressions of orthodoxy. This can be deduced as the result of enculturation and self-definition, as respective Christian elements in Pakistan inclined towards an indigenous expression of Christianity. This was evident, for example, in the adoption of this respective cross sign as a symbol by the Church of Pakistan, and the denomination was a localised amalgamation of Presbyterians, Anglicans, United Methodists and Lutherans. This has parallels to Ethiopian Christianity.

When the resultant continuum, consequent of the authentication of the Thomine legend by archaeological finds, is identified as an affirmation of localised Christian tradition, certain implications follow. As stated earlier, the entrenchment of local Christian tradition enhances the momentum for indigenous expressions of Christianity.

This appears to be the case with Ethiopian Christianity, which is notably dominated by the indigenous Ethiopian Orthodox Tawahido Church. The denomination by proxy is the custodian of Christian tradition in Ethiopia (cf. Isaac 2011). The efficiency and capacity of the Tawahido Church as an indigenous expression of Christianity in Ethiopia is arguably a direct function of the affirmed historical Christian tradition of Ethiopia. The claim to antique origins of Christianity that connect to Ethiopia's Judaic links, created and held a resonant enculturate momentum amongst the natives, ensuring the church's survival amidst turbulent political-religious dynamics in the region of Ethiopia. Challenges to the efficacy of this theory arise in the limelight of discrediting revisionist archaeology and history - this has been the case with Indian tradition as well. In addition, the falsification of historical data in the name of Christianity as consistent with missionary momentum of the 1990s did not help as well.

The revisionist identification of Buddhist scared spaces as shrines for Thomine legend creates ground for critics of the Christian narrative. In another perspective, it appears that the entrenchment of the Thomine tradition dually implies the cost of foregoing local Hindu tradition; this is consequent of the two establishments' competition for authentication through the archaeology of religion. The medieval-like ecclesiastical reaffirmation of the relics and hagiographical legends is implied in the rededication of several Hindu temples as monumental Thomine Christian churches (Kalyanaraman 2019:4-6). Although arguably this does not negate the eventuality of the 1st century reality of the Thomine mission to India, this is true just as the medieval ages' mythification of 1 st century apostolic figures does not negate their historicity.

Who has not been startled at the deification of St Peter in other extra-biblical legends? Yet, this does not disqualify the intrinsic biblical argument for Petrine apostleship. The medieval era is replete with incidences and narratives that index the church's power play within the feudal world. The claim by the church to have relics and bones of saints, the milk from the breast of the virgin Mary, thorns and nails that pierced Jesus' side is notable. Whereas the previous assertion relates to the debate between Martin Luther and the church over the authority of scripture and tradition (Christin 2006:307), there is another related argument regarding the essential nature of Jesus.

The fragment of the true cross was a source of contention and a motivator for crusaders in the Orient at the instruction of the Church (Tyerman 2006:63). The recovery of a fragment of the true cross added the impetus to fund the religious war between Christianity and Islam during the crusades (Tyerman 2006:65).

The very definition of crusading emanated from cross bearing on the gowns and shields of the knights. This perceivable misconstruing of Jesus' means of death as an object for rallying military campaigns for control of the orient does not deconstruct the historicity of Jesus (ed. Madden 2002:33; Richard 1999:218; Tyerman 2006:70).

The above-mentioned examples further substantiate the fact that a later misconception of a historical tradition cannot serve as substantial ground to deny the historicity of the event intrinsically. This bears extended significance in the construction of a 1st century account for apostolic Christianity in Ethiopia.

Although independent and severed geographically, the narratives of Ethiopian and Indian Christianity are symbiotically correlated and by implication there is a direct attachment between the two. The reality of 1st century apostolic Christian activity in India when placed in perspective of the maritime connections of the then world substantiates the possibility of a 1st century Ethiopian apostolic Christian narrative.

According to Rashid, the Taxila cross find of 1935 bore intrinsic limitations in its authenticity as an archaeological affirmation of the legend of Thomas. The cross was after all found outside the city ruins of Sirkap by a local farmer and not within the datable stratum of the archaeological site through excavation 
(Rashid 2014). This argument is premised on the technical implications for the definition of perimeters in the areal scope of excavation (cf. Insoll 2004). That is, the archaeological finds should be the guide to the determination of the historical site. Therefore, by being disassociated with its context, the cross loses archaeological credibility. The cross is one of many finds, and therefore, for archaeological authenticity, it would be appropriate to evaluate all of them with their respective settings and dates; however, this is beyond the scope of this article.

The Thomine tradition has received endorsement from Christian influencers, such as Pope Benedict XVI, although even within this affirmation there is a divergence with the idea that it was firstly India. There is support for the alternate theory that Thomas first went to modern day northeastern Iran, then Parthian Persia, then India, Afghanistan and Pakistan, which were Indo-Parthian regions (Medleycott 1905; Panikkar 1945).

The recent research on the ancient Kerala Spice Route is an attempt at deducing the capability of maritime links in the spread of civilisation, in this case Christianity (Tomber 2008).
This momentum perceivably is positive for the development of an integrated narrative of 1st century Christianity, which would include Ethiopian Aksum. This finds justification additionally because of the direct link established through the reality of maritime connections between Aksumite-Adulis and Malabar. Indirectly, research on the late BCEs' and early $\mathrm{CEs}^{\prime}$ economic-social inter-exchange between Rome and India is extendedly a prelude to positioning Ethiopia amidst the realities assigned to this respective era. Whilst another direct link stems from the connection of Indian-Syrian Christian connection that was consequent of Syrian migration into India and Thomas' said mission to Syria. The SyrianIndian Christian link can chronologically be categorised as a consequence of the 3rd or 4th century Christian dynamics on Ethiopia and its connection with the broader Christian world.

\section{Conclusion}

Considering 1st century CE, account for Ethiopian Christianity in perspective of Indian Christianity probes an archaeological enquiry. Whereas for Indian Christianity and the tradition of Thomas, this (archaeological enquiries) has been realised, for Ethiopia the reality of archaeology

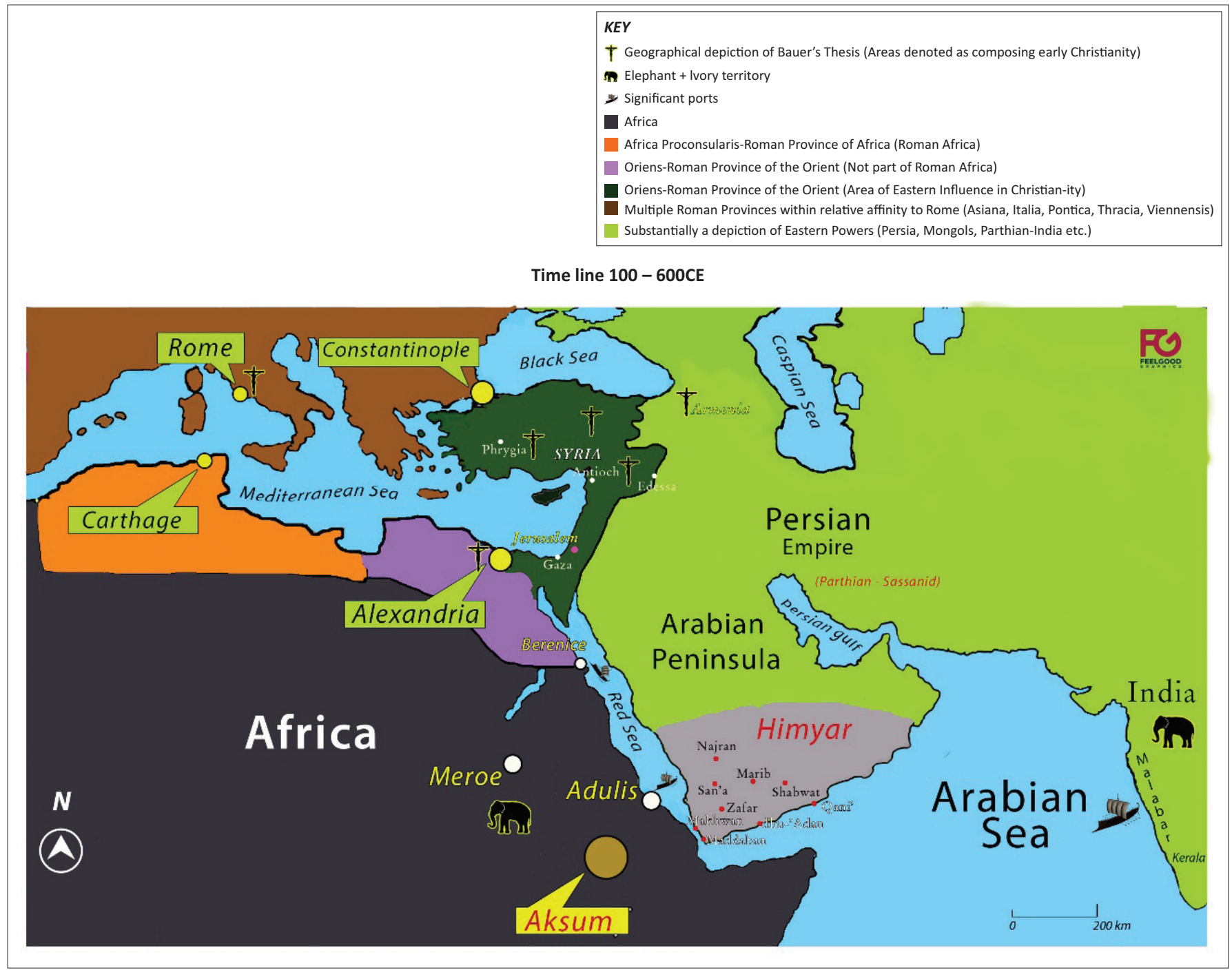

FIGURE 1: A map illustrating issues inside this article by Rugare Rukuni. 


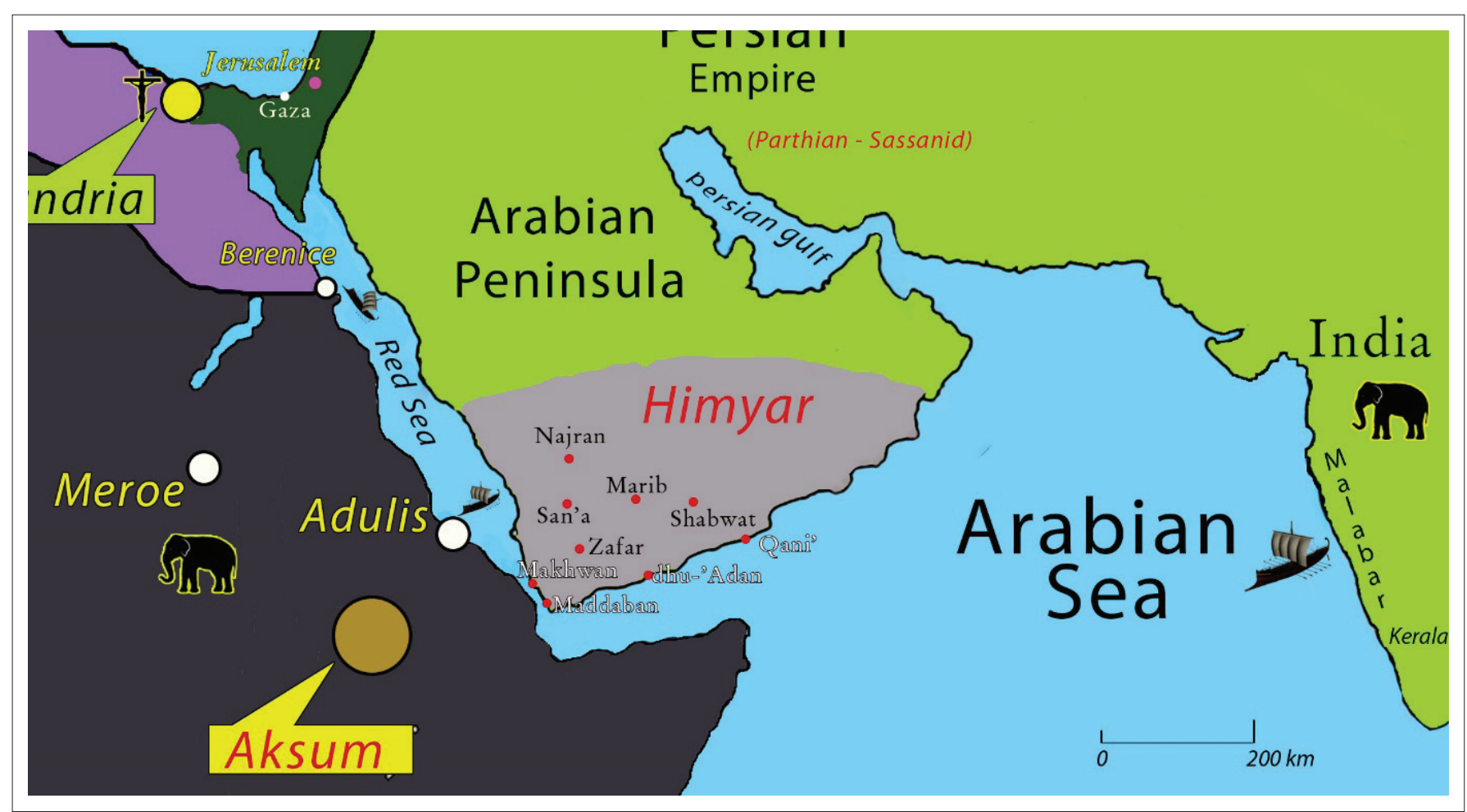

FIGURE 2: Zoomed excerpt indicating particular regions.

determining the character and origins of Christianity is applicable post 333 EC (Ethiopian Calendar), during the reign of Ezana (Munro-Hay 1988:111-127).

Pre-4th century CE, Ethiopian archaeology is not as concerned with the narrative of a diplomat who encountered a 1st century Christian character on a 'possible' land route from Jerusalem. The replete evidence regarding integrated maritime connections in which featured Ethiopian Adulis, the aggregately affirmable tradition of Thomas and his missionary endeavours in the East, Parthia and India entail considerable basis for an investigation regarding the phenomenon of 1st century Christianity, possibly in Ethiopia. The common geographical-chronological nexus of Israelite influence on both Ethiopia and India weighs in on the case of similar circumstances regarding contact with Christianity. Adoption of archaeological-anthropological theorem in the study of Christianity can add to the synthesis of an early Ethiopian Christianity. Aggregately, an establishment of the subject of a 1st century Ethiopian Christianity redefines the texture of Ethiopian Christianity and deconstructs the connotations of 'Syrian' and 'Coptic'.

Figure 1 is a map illustrating issues inside this article by Rugare Rukuni (own archive), and Figure 2 is a zoomed excerpt indicating particular regions.

\section{Acknowledgements Competing interests}

The authors have declared that no competing interests exist.

\section{Author's contributions}

I declare that I am the sole author of this research article.

\section{Ethical consideration}

This article followed all ethical standards for a research without direct contact with human or animal subjects.

\section{Funding information}

This research received no specific grant from any funding agency in the public, commercial or not-for-profit sectors.

\section{Data availability statement}

Data sharing is not applicable to this article as no new data were created or analysed in this study.

\section{Disclaimer}

The views and opinions expressed in this article are those of the authors and do not necessarily reflect the official policy or position of any affiliated agency of the authors.

\section{References}

Alexander, D.C. \& Smither, E.L., 2015, 'Bauer's forgotten region: North African Christianity', in P.A. Hartog (ed.), Orthodoxy and heresy in early Christian contexts: Reconsidering the Bauer thesis, pp. 166-192, Pickwick Publications, Eugene, OR.

Amidon, P.R., 1997, The church history of Rufinus of Aquileia, books 10 \& 11, Oxford University Press, New York, NY.

Bauer, W., 1971, Orthodoxy and heresy in earliest Christianity, 2nd edn., Fortress, Philadelphia, PA.

Bausi, A. (ed.), 2012, Languages and cultures of Eastern Christianity: Ethiopian (The worlds of Eastern Christianity, pp. 300-1500, vol. 4.), Ashgate Publishing Ltd, Surrey. 
Behr, J., 2004, The Nicene faith: Formation of Christian theology, vol. 2, St Vladimir's Seminary Press, Crestwood, MO.

Bhaskaran, V.P., 2012, The legacy of St Thomas, apostle of India, St Paul's, Mumbai.

Binford, L., 1962, 'Archaeology as anthropology', American Antiquity 28(2), 217-225. https://doi.org/10.2307/278380

Binns, J., 2017, The orthodox church of Ethiopia: A history account, I.B. Tauris, London

Bowen, G.A., 2009, 'Document analysis as a qualitative research method', Qualitative Research Journal 9(2), 27-40. https://doi.org/10.3316/QRJ0902027

Bowersock, G.W., 2013, The throne of Adulis: Red Sea wars on the eve of Islam, Oxford University Press, New York, NY.

Boyarin, D., 2010, 'Judaism as a free church: Footnotes to John Howard Yoder's the Jewish-Christian schism revisited', in P. Dula \& C.K. Huebner (eds.), The New Yoder pp. 1-17, Cascade Locks, OR.

Brown, L.W., 1956, The Indian Christians of St Thomas, Cambridge University Press, Cambridge.

Budge, E.W., 2000, The queen of Sheba and her only son Menyelek: Kebra Nagast, Ethiopian Series, Cambridge Publications, Ontario.

Carson, D.A., Desmond A.T., Hess, R., Moo, D.J. \& Naselli, A.D., 1973-2014, The holy Bible new international version (NIV): Study Bible, Zondervan Bible Publishers, Grand Rapids, Ml, viewed 14 November 2019, from https://www.biblica.com/ Grand Rapids,
bible/niv/acts1.

Casson, L., 1989, The Periplus Maris Erythraei, Princeton University Press, Princeton, NJ.

Cerulli, E., 1959, 'Perspectives on the history of Ethiopia (Punti di vista sulla storia dell'Etiopia)', republished in Bausi, A., (ed.), 2012, Lanquages and cultures of Eastern Christianity: Ethiopian, pp. 1-25, Ashgate Publishing Ltd, Surrey.

Christin, O., 2006, 17-Religious colloquies and toleration, pp. 302-320.

Dales, G.F., 1968, 'A review of the chronology of Afghanistan, Baluchistan and the Indus Valley', American Journal of Archaeology 72(4), 305-307. https://doi. org/10.2307/503821

Danto, E.A., 2008, 'Historical research', Oxford Scholarship, viewed 12 January 2018 from https://www.oxfordscholarship.com/view/10.1093/acprof:oso/9780195333 060.001.0001/acprof-9780195333060.

Dashu, M., 2012, Makeda, the queen of Sheba (Saba'), Suppressed Histories Archives, CA.

Davidson, I.J., 2004, The birth of the church: From Jesus to Constantine, A.D. 30-312, Monarch Books, Oxford.

De Pujol, A.D.A., 1848, Saint Philip baptizing the queen of Ethiopia's eunuch on the road from Jerusalem to Gaza, Reunion des Musees Nationaux/Art Resource, NY, viewed 28 May 2019, from https://www.artres.com/c/htm/Home.aspx.

Dewing, H.B. (ed. \& transl.), 1914-1928, Procopius: History of the wars, Heinemann (Loeb Classical Library), taken from wikisource: History of the Wars/Book I. (03 May 2017), Wikisource, London, viewed 06 November 2018, from https:// en.wikisource.org/w/index.php?title=History_of_the_Wars/ Book_I\&oldid=6790552.

Finneran, N., 2007, The archaeology of Ethiopia, Routledge, London.

Gorder, A.C.V., 2010, Christianity in Persia and the status of non-Muslims in Iran Lexington Books, Lanham, MD.

Hendrickx, B., 2017, 'Letter of Constantius II to Ezana and Sezana: A note on its purpose, range and impact in an Afro-Byzantine context', Graeco-Arabica 12, 545-556.

Inowlocki, S. \& Zamagni, C., 2011, Reconsidering Eusebius: Collected papers on literary, historical, and theological issues, Brill, Leiden.

Insoll, T., 2004, Archaeology, ritual, religion, Routledge, London.

Isaac, E., 2013, The Ethiopian orthodox Tawahido church, The Red Sea Press, Trenton, NJ.

James, M.R. (ed. \& transl.), 1924, The apocryphal New Testament, Clarendon Press, Oxford (this edition 2006, A. Muller transl.).

Jha, D.N., 1998-2010, Ancient India: In historical outline, Manohar, New Delhi.

Jones, H.L. (ed. \& transl.), 1917-1932, The geography of Strabo with an English translation, vol. 8, Harvard University Press (Loeb Classical Library), Heinemann, London.

Kalyanaraman, S., 2019, Itihāsa, historical hoax of St. Thomas and the dubious 'Taxila cross': B.S. Harishankar, Indus script Cipher debunks the hoax, Sarasvati Research Centre, Chennai.

Kaplan, S., 1982, 'Ezana's conversion reconsidered', Journal of Religion in Africa 13(2), 101-109. https://doi.org/10.1163/157006682X00087

Katz, N., 2000, Who are the Jews of India?, University of California Press, Los Angeles, CA

Kirby, P., 2001-2019, 'The Muratorian fragment', Early Christian writings, viewed 15 November 2019, from https://www.earlychristianwritings.com/text/muratorian2. html.

Lee, A.D., 2006, 'Traditional religions', in N. Lenski (ed.), The Cambridge companion to the age of Constantine, pp. 159-180, Cambridge University Press, New York, NY.

Madden, T.F. (ed.), 2002, The crusades: The essential readings, Blackwell Publishers Ltd, Oxford.

Medleycott, A.E., 1905, India and the apostle Thomas: An inquiry, with a critical analysis of the Acta Thomae, David Nutt, London.

Mitchell, M.M., 2006, 'From Jerusalem to the ends of the Earth', in M.M. Mitchell \& F.M. Young (eds.), The Cambridge history of Christianity: Origins to Constantine, pp. 295-301, Cambridge University Press, New York, NY.
Moffet, S.H., 1998, A history of Christianity in Asia. Volume I. Beginnings to 1500, Orbis Books, New York, NY.

Munro-Hay, S., 1988, 'The dating of Ezana and Frumentius', Rassegna di Studi Etiopici $32,111-127$.

Munro-Hay, S., 2005, 'Saintly shadows', in W. Raunig \& S. Wenig (eds.), Afrikas Horn Akten der Ersten International Littman-Konferenz 2. Bis 5. Mai 2002 in Munchen, Meroitica, vol. 22, pp. 137-168, Otto Harrassowitz Gmbh \& Co. KG, Wiesbaden.

Nickelsburg, G.W.E., 2003, Ancient Judaism and Christian origins: Diversity, continuity and transformation, Fortress Press, Minneapolis, MN.

O'Bannon, K., 2016, Josephus: The complete works, Christian Classics Ethereal Library, Grand Rapids, MI.

Panikkar, K.M., 1945, India and the Indian Ocean, Mcmillan Company, New York, NY.

Philip, E.M., [1908]2002, The Indian church of St. Thomas, Mor Adai Study Centre, Changanacherry.

Phillipson, D.W., 2012, Foundations of an African civilisation: Aksum \& the Northern Horn 1000 BC-AD 1300, James Currey, New York, NY.

Pothan, S.G., 1968, The Syrian Christians of Kerala, 4th edn., K.M. Cherian, Madras.

Rapson, E.J. (ed.), 1922, The Cambridge history of India, vol. 1, Cambridge University Press, Cambridge.

Rashid, S., 2014, Taxila Cross, viewed 09 October 2019, from odysseuslahori.blogspot. com/2014/07/TaxilaCross.html.

Richard, J., 1999, The crusades: c.1071-c.1291, Cambridge University Press, Cambridge.

RIE I-III., Bernand, E., Drewes, A.J. \& Schneider, R., 1991-2000, Recueil des inscriptions de l'Ethiopie des periodes preaxoumite et axoumite, introduction by Fr. Anfray, 3 vols, Vol 1, Les documents, Vol 2, Lesplanches, Vol. 3, Traductions et commentaires A. Les inscriptions grecques par E. Bernand, Paris.

Ritchie, J. \& Lewis, J., 2003, Qualitative research practice: A guide for social science students and researchers, Sage, London.

Rodinson, M., 1964a, 'On the question of "Jewish influences" in Ethiopia, (Sur la question des “influence juives" en Ethiopie)', Journal of Semitic Studies 9(1), 1119. https://doi.org/10.1093/jss/9.1.11

Rodinson, M., 1964b, 'Review of Edward Ullendorff', The Ethiopians, Bibliotheca Orientalis 21(1964), 238-245.

Roldanus, J., 2006, The Church in the age of Constantine: The theological challenges, Routledge, London.

Rukuni, R., 2018, The schism, hellenism and politics: A review of the emergence of Ecumenical orthodoxy AD 100-400, UNISA, Pretoria.

Schaff, P. (ed.), 1885a, Ante-Nicene fathers. Vol. 3: Latin Christianity: Its founder, Tertullian, Christian Classics Ethereal Library, Grand Rapids, MI.

Schaff, P. (ed.), 1885b, Nicene and post-Nicene fathers: Series 2, vol. 1: Eusebius Pamphilius: Church history, life of Constantine, oration in praise of Constantine, Christian Classics Ethereal Library, Grand Rapids, MI.

Schaff, P. (ed.), 1885c, Nicene and post-Nicene fathers: Series 2, vol. 3: Theodoret Jerome, Gennadius, \& Rufinus: Historical writings, Christian Classics Ethereal Library, Grand Rapids, Ml.

Schoff, W.H. (ed. \& transl.), 1912, Periplus Maris Erythraei (the Periplus of the Erythraen Sea: Travel and trade in the Indian Ocean), Longmans, Green, New York, NY.

Smith, V.A., 1906, Catalogue of the coins in the Indian museum in Calcutta, Oxford, Kolkata.

Skolnik, F. \& Berenbaum, M., 2007, Encyclopedia Judaica, vol. 9, MacMillan, New York, NY.

Tanner, N.P. (ed.), 1990, Decrees of the Ecumenical councils, vol. 1, Nicaea I to Lateran V, Georgetown University, Washington, DC.

Thapar, R., 2015, The Penguin history of early India: From the origins to AD 1300 Penguin Books, Delhi.

The Holy Bible: King James Version, 2009, Electronic Edition of the 1900 Authorized Version., Ac 8:28-38, Logos Research Systems, Inc, Bellingham, WA

Thomaskutty, J., 2018, Saint Thomas the apostle: New Testament, Apocrypha, and historical traditions, Bloomsbury T \& T Clark, London.

Tilley, M.A., 2006, 'North Africa', in M.M. Mitchell \& F.M. Young (eds.), The Cambridge history of Christianity: Origins to Constantine, pp. 485-503, Cambridge University Press, New York, NY.

Tomber, R.S., 2008, Indo-Roman trade: From pots to pepper, Duckworth, London.

Trombley, F., 2006, 'Overview: The geographical spread of Christianity', in M.M. Mitchell \& F.M. (eds.), The Cambridge history of Christianity: Origins to Constantine, pp. 302-313, Cambridge University Press, New York, NY.

Tyerman, C., 2006, God's war: A new history of the Crusades, Penguin Group, London. https://doi.org/10.1093/actrade/9780192806550.001.0001

Ullendorff, E., 1956, 'Hebraic-Jewish elements in Abyssinian (Monophysite) Christianity', Journal of Semitic Studies 1(3), 216-256. https://doi.org/10.1093/ Christianity',
jss/1.3.216

Ullendorff, E., 1960, The Ethiopians, Oxford University Press, Oxford.

Wilhite, D.E., 2017, Ancient African Christianity: An introduction to a unique context and tradition, Routledge, New York, NY

Wolska-Conus, W., 1968-1973, Cosmas Indicopleustès: Topographie Chrétienne, (sources chrétiennes 141, 159, 197), vol. 3, Editions du Cerf, Paris.

Yamauchi, E.M., 1972, The stones and the scriptures, Holman, New York, NY. 